\title{
RESEARCH
}

\section{DEATH ANXIETY AND CONCEPT OF GOOD DEATH IN THE ELDERLY}

Turkish Journal of Geriatrics

DOI: $10.31086 /$ tigeri.2020.133

2020; 23(1): 18-26

n Deniz SAY ŞAHIN ${ }^{1}$ (D)

- Nüket ÖRNEK BÜKEN² (D)
CORRESPONDANCE

Deniz SAY ŞAHIN

Mehmet Akif Ersoy University, Faculty of

Economics and Administrative Sciences, Social

Work, Burdur, TURKEY.

Phone: +905052362620

e-mail: saysahind@mehmetakif.edu.tr

Received: 08/11/2019

Accepted: $31 / 01 / 2020$

${ }^{1}$ Mehmet Akif Ersoy University,Faculty of

Economics and Administrative Sciences,

Social Work, Burdur, TURKEY.

${ }^{2}$ Hacettepe University, Medical School, History

of Medicine and Medical Ethics, Ankara,

TURKEY.

\section{A}

Introduction: We aimed to determine what elderly individuals think about good death and their level of anxiety about death in order to guide people and families working with elderly individuals.

Materials and Method: 420 volunteer elderly participated in the study. Questionnaires were conducted using face to face interview technique. The measured values were calculated as arithmetic mean and standard deviation, while values determined by counting as number and percent. The significance of the difference between the means of the groups was evaluated using the T-test for 2-independent samples for two measured values, the One-Way ANOVA test for comparison of three and more measured variables, and the Tukey's post-hoc test for determining the factor that caused the significance.

Results: The importance given to psychosocial and spiritual aspect, personal control and clinical aspect of death were found to be high in elderly individuals, having a near death experience and having children are factors that increase death anxiety of elderly people. Elderly women have higher death anxiety, and death anxiety decreases with age. It was found that thinking of death frequently increases death anxiety.

Conclusion: As a decent and fair life befitting human dignity is an indispensable right for all people, decisions regarding the last period of life and the desire for a good death are equally indispensable rights for all people and all age groups, and applications in practice should be shaped according to these needs.

Key Words: Aged; Anxiety; Death; Attitude. 


\section{INTRODUCTION}

Although death and life are understood as opposing concepts, they actually constitute a whole in human life. Namely, death, which means the end of life, is also defined in some sources as the purpose of life and actually complements life. In different cultures, societies and disciplines, very different definitions of death have been made, which also vary depending on the personality, age, religion and cultural position of the individual. The common points in all these definitions include the loss of ability of the living organism to regenerate itself and the inevitable end of life by complete dysfunction of one or more vital organs. Individually and socially, death has never been viewed as a simple event (1-4). Death alone is a cause of concern both for the individual himself/herself and his/her relatives. Understanding the cause of this anxiety and knowing how to reduce it will comfort both the individual and the family emotionally. For this reason, studies have been carried out on people from all age groups on how they want to die in an attempt to determine what is important for people at the time of death. Consequently, although not spoken, people have some expectations about their own deaths, and meeting these expectations is one of the factors that reduce anxiety (3-7). Especially older individuals are more associated with the concept of death as they are closer to the end of their life expectancy, and it is a fact that mortality rate at younger ages is lower compared to that of the elderly. Knowing the thoughts of elderly people about the concept of good death and their anxiety levels about death is important for the relatives of the elderly and healthcare professional groups working with the elderly. Knowing the elderly individuals' wishes about death and providing them a death as they wish will reduce the spiritual burden on family and health personnel and allow them to deal with this situation more easily. Therefore, in this study, we aimed to determine what elderly individuals think about good death and their level of anxiety about death in order to guide people and families working with elderly individuals.

\section{METHOD}

\section{Sampling}

The population of the study consists of individuals aged 65 and over who live in the city center of Burdur. According to the address-based population registration system for 2018, the population of Burdur city center aged 65 and over is 12.378 . In the study, the sample size was calculated as 378 individuals in Epi-info software with a 5\% acceptable error level, 95\% confidence interval and 50\% probability of occurrence within the main mass. The questionnaires were applied using face-to-face interview technique to 420 volunteer participants aged 65 years and over who presented to the Burdur State Hospital outpatient clinics between April 01, 2017 and October 01, 2018.

\section{Data Collection Tools}

1. Socio-demographic characteristics data form: A questionnaire created by us including questions such as gender, age, marital status, number of children, family type, educational status, whether they think of death frequently, whether they had near-death experience (past heart attack, serious accident requiring long-term intensive care, a history of injury and/or surgery, having a fatal disease such as cancer, etc.).

2. Death Anxiety Scale (DAS): In the study, the Death Anxiety Scale (DAS) was used to determine anxiety levels of the elderly individuals; this scale was developed by Templer in 1970 (8), and its validity and reliability study for Turkish population was conducted by Akça (9).

3. Good Death Scale (GDS): The scale was developed by Schwartz et al. in 2003 to determine the concept and characteristics of a good death (10). The Turkish validity and adaptation of the scale, which consists of 17 questions and 3 sub-dimensions, was conducted by Fadıloğlu and Menekli (11). 


\section{Ethical Dimension of Research}

Before initiating the study, ethical approval was obtained from the Mehmet Akif Ersoy University Non-Interventional Research Ethics Committee (No: GO2017/76).

\section{Statistical Evaluation}

The data obtained from the study were analyzed using the "SPSS 20.0 for Windows" software, and the measured values were calculated as arithmetic mean and standard deviation, while values determined by counting as number and percent. The significance of the difference between the means of the groups was evaluated using the T-test for 2-independent samples for two measured values, the One-Way ANOVA test for comparison of three and more measured variables, and the Tukey's post-hoc test for determining the factor that caused the significance. Cronbach's alpha was used to determine the consistency of the scales, the Pearson correlation method was used to determine the relationship between the scales, and the Kruskal-Wallis analysis was used for data without normal distribution.

\section{RESULTS}

When the demographic characteristics of the elderly participating in the study were examined, it was determined that $26.6 \%$ of the participants had a near-death experience (previous heart attack, conditions requiring long-term intensive care, having a fatal disease such as cancer), $53.6 \%$ of them were female, the mean age was $72.5 \pm 1.2,99.1 \%$ of them had children, and $41.6 \%$ of them were educated at primary school level (Table 3 ).

Table 1. Elderly individuals' thoughts on death anxiety.

\begin{tabular}{|c|c|}
\hline Answers for the Death Anxiety Scale & $\begin{array}{r}\text { Correct } \\
\text { n (\%) }\end{array}$ \\
\hline 1. I am very afraid of dying. & $301(71,6)$ \\
\hline 2. I'm often troubled with the fact that time passes so fast. & $236(56,1)$ \\
\hline 3. I'm afraid when I think I will undergo surgery. & $385(91,6)$ \\
\hline 4. I often think about how short life really is. & $320(76,1)$ \\
\hline 5. Life after death worries me greatly. & $380(90,4)$ \\
\hline 6. I'm really afraid of having a heart attack. & $400(95,2)$ \\
\hline 7. Appearance of a corpse terrifies me. & $51(12,1)$ \\
\hline 8. Talking about outbreak of a world war scares me. & $73(17,3)$ \\
\hline 9. I'm afraid of dying in agony. & $403(95,9)$ \\
\hline 10. I'm not afraid of dying. & $119(28,4)$ \\
\hline 11. I feel there is nothing to fear for me in the future. & $230(54,7)$ \\
\hline 12. I don't have a particular fear of getting cancer. & $227(54)$ \\
\hline 13. I don't get nervous when people talk about death. & $318(75,7)$ \\
\hline 14. The thought of death never worries me. & $65(15,4)$ \\
\hline 15. The thought of death comes to my mind occasionally. & $325(77,3)$ \\
\hline
\end{tabular}


The DAS scores of the participants were examined, and the total death anxiety score was determined as $8.62 \pm 2.75$ (moderate anxiety). The DAS Cronbach's alpha value was 0.804 , and the consistency was found to be good. It was determined that more than $90 \%$ of elderly individuals were afraid of dying in agony, having a heart attack and having surgery (Table 1).

Table 2. Elderly individuals' view on concept of good death.

\begin{tabular}{|c|c|c|c|}
\hline \multicolumn{2}{|c|}{ Answers for the Death Anxiety Scale } & \multirow{2}{*}{$\begin{array}{r}\begin{array}{r}\text { Correct } \\
\text { n (\%) }\end{array} \\
3,47\end{array}$} & \multirow{2}{*}{$\begin{array}{r}\begin{array}{r}\text { Correct } \\
\text { n (\%) }\end{array} \\
0,71\end{array}$} \\
\hline \multirow{8}{*}{$\begin{array}{l}\text { Psychosocial } \\
\text { and spiritual } \\
\text { subdimension } \\
(3.63 \pm 0.66)\end{array}$} & Family and doctors observing one's wishes (4) & & \\
\hline & Peaceful death (6) & 3,83 & 0,62 \\
\hline & Presence of beloved ones (7) & 3,68 & 0,63 \\
\hline & Meeting one's spiritual needs (8) & 3,81 & 0,62 \\
\hline & Ability to accept death (9) & 3,72 & 0,68 \\
\hline & Having a chance to complete one's important tasks (10) & 3,89 & 0,78 \\
\hline & Having an opportunity to say goodbye to loved ones (11) & 3,93 & 0,61 \\
\hline & Being at home (12) & 3,22 & 0,78 \\
\hline \multirow{3}{*}{$\begin{array}{l}\text { Personal control } \\
\text { subdimension } \\
(3.28 \pm 0.51)\end{array}$} & Having intact mental functioning until death (15) & 3,43 & 0,63 \\
\hline & Having control of bodily functions until death (16) & 2,96 & 0,88 \\
\hline & Ability to communicate until death (17) & 3,47 & 0,83 \\
\hline \multirow{5}{*}{$\begin{array}{l}\text { Clinical subdimension } \\
(3.41 \pm 0.81)\end{array}$} & Having a painless or substantially painless death (1) & 3,92 & 0,81 \\
\hline & Short death time (2) & 3,37 & 0,76 \\
\hline & Sudden and unexpected death (3) & 3,34 & 0,81 \\
\hline & Natural death without technical means (5) & 3,11 & 0,68 \\
\hline & Death during sleep (14) & 3,31 & 0,77 \\
\hline
\end{tabular}

In this study, the consistency of the subdimensions of the good death scale, which was applied to determine which dimensions of death were given importance, was measured, and the Cronbach's alpha value was 0.888 for psychosocial and spiritual subdimension, 0.889 for personal control subdimension, and 0.823 for clinical subdimension, hence they were found to be quite consistent. It was determined that the importance given to psychosocial and spiritual aspect, personal control and clinical aspect of death, which are subdimensions of the scale, were found to be high in elderly individuals (Table 2). 
Table 3. Factors affecting the concept of good death and death anxiety according to sociodemographic characteristics (Univariate analysis)

\begin{tabular}{|c|c|c|c|c|c|c|}
\hline \multirow{3}{*}{\multicolumn{2}{|c|}{ Sociodemographic Characteristics }} & \multirow{4}{*}{$\begin{array}{l}\begin{array}{l}\text { Number- } \\
\text { Percent } \\
\text { n (\%) }\end{array} \\
256(\% 60,9) \\
121(28,8) \\
43(10,3) \\
\end{array}$} & \multicolumn{3}{|c|}{ GDS Subdimensions } & \multirow{3}{*}{$\begin{array}{r}\begin{array}{r}\text { Death } \\
\text { Anxiety }\end{array} \\
\text { Mean } \pm \text { SD } \\
\end{array}$} \\
\hline & & & \multirow{2}{*}{\begin{tabular}{|r|}
$\begin{array}{r}\text { Psychosocial } \\
\text { \& Spiritual }\end{array}$ \\
Mean \pm SD \\
\end{tabular}} & \multirow{2}{*}{$\begin{array}{r}\begin{array}{r}\text { Personal } \\
\text { Control }\end{array} \\
\text { Mean } \pm \text { SD } \\
\end{array}$} & \multirow{2}{*}{$\begin{array}{r}\text { Clinical } \\
\text { Mean } \pm \text { SD } \\
\end{array}$} & \\
\hline & & & & & & \\
\hline \multirow{2}{*}{ Age } & \multirow{2}{*}{$\begin{array}{l}\text { a. } 65-74 \\
\text { b. } 75-84 \\
\text { c. } 85 \text { and above }\end{array}$} & & $\begin{array}{r}3,51 \pm 0,55 \\
3,58 \pm 0,56 \\
3,60 \pm 0,48 \\
\end{array}$ & $\begin{array}{l}3,37 \pm 0,68 \\
3,25 \pm 0,61 \\
3,25 \pm 0,51 \\
\end{array}$ & $\begin{array}{l}3,48 \pm 0,67 \\
3,46 \pm 0,62 \\
3,36 \pm 0,61 \\
\end{array}$ & $\begin{array}{l}9,82 \pm 2,69 \\
8,99 \pm 3,02 \\
7,56 \pm 3,16 \\
\end{array}$ \\
\hline & & (p) & $\begin{array}{l}a-b=0,278 \\
a-c=0,387 \\
b-c=0,392\end{array}$ & $\begin{array}{l}a-b=0,196 \\
a-c=0,189 \\
b-c=0,436\end{array}$ & $\begin{array}{l}a-b=0,173 \\
a-c=0,192 \\
b-c=0,296\end{array}$ & $\begin{array}{l}a-b=0,009 \\
a-c=0,001 \\
b-c=0,006\end{array}$ \\
\hline Gender & $\begin{array}{l}\text { Male } \\
\text { Female } \\
\text { (p) }\end{array}$ & $\begin{array}{l}195(46,4) \\
225(53,6)\end{array}$ & $\begin{array}{r}3,57 \pm 0,74 \\
3,78 \pm 0,52 \\
(0,005) \\
\end{array}$ & $\begin{array}{r}3,08 \pm 0,81 \\
3,41 \pm 0,59 \\
(0,002) \\
\end{array}$ & $\begin{array}{r}3,21 \pm 0,73 \\
3,44 \pm 0,64 \\
(0,004) \\
\end{array}$ & $\begin{array}{r}6,69 \pm 2,29 \\
8,97 \pm 3,16 \\
(0,005) \\
\end{array}$ \\
\hline \multirow[b]{2}{*}{ Income status } & \multirow{2}{*}{$\begin{array}{l}\text { a. Less than expenses } \\
\text { b. Equal to expenses } \\
\text { c. More than expenses }\end{array}$} & $\begin{array}{r}56(13,4) \\
324(77,1) \\
40(9,5\end{array}$ & $\begin{array}{l}3,54 \pm 0,45 \\
3,50 \pm 0,46 \\
3,52 \pm 0,48\end{array}$ & $\begin{array}{l}3,27 \pm 0,64 \\
3,15 \pm 0,62 \\
3,21 \pm 0,53\end{array}$ & $\begin{array}{l}3,38 \pm 0,63 \\
3,40 \pm 0,61 \\
3,36 \pm 0,67\end{array}$ & $\begin{array}{l}8,22 \pm 2,69 \\
8,39 \pm 3,02 \\
8,26 \pm 3,16\end{array}$ \\
\hline & & (p) & $\begin{array}{l}a-b=0,478 \\
a-c=0,362 \\
b-c=0,322\end{array}$ & $\begin{array}{l}a-b=0,563 \\
a-c=0,186 \\
b-c=0,391\end{array}$ & $\begin{array}{l}a-b=0,216 \\
a-c=0,196 \\
b-c=0,288\end{array}$ & $\begin{array}{l}a-b=0,716 \\
a-c=0,821 \\
b-c=0,842\end{array}$ \\
\hline \multirow[t]{2}{*}{ Marital status } & $\begin{array}{l}\text { Married } \\
\text { Single } \\
\text { Divorced/Widowed }\end{array}$ & $\begin{array}{r}307(73) \\
4(0,9) \\
109(26,1) \\
\end{array}$ & $\begin{array}{l}3,74 \pm 0,51 \\
3,89 \pm 0,54 \\
3,71 \pm 0,56 \\
\end{array}$ & $\begin{array}{l}3,38 \pm 0,71 \\
3,29 \pm 0,74 \\
3,39 \pm 0,71\end{array}$ & $\begin{array}{l}3,32 \pm 0,69 \\
3,39 \pm 0,60 \\
3,31 \pm 0,41\end{array}$ & $\begin{array}{l}8,14 \pm 2,99 \\
7,82 \pm 3,35 \\
8,97 \pm 3,46\end{array}$ \\
\hline & & (p) & $\begin{array}{l}a-b=0,338 \\
a-c=0,197 \\
b-c=0,480\end{array}$ & $\begin{array}{l}a-b=0,356 \\
a-c=0,361 \\
b-c=0,342\end{array}$ & $\begin{array}{l}a-b=0,123 \\
a-c=0,344 \\
b-c=0,112\end{array}$ & $\begin{array}{l}a-b=0,268 \\
a-c=0,198 \\
b-c=0,212\end{array}$ \\
\hline Child & $\begin{array}{l}\text { Yes } \\
\text { No } \\
\text { (p) }\end{array}$ & $\begin{array}{r}416(99,1) \\
4(0,9)\end{array}$ & $\begin{array}{r}3,79 \pm 0,58 \\
3,51 \pm 0,51 \\
(0,001) \\
\end{array}$ & $\begin{array}{r}3,56 \pm 0,71 \\
3,24 \pm 0,79 \\
(0,001) \\
\end{array}$ & $\begin{array}{r}3,37 \pm 0,56 \\
3,17 \pm 0,65 \\
(0,004) \\
\end{array}$ & $\begin{array}{r}9,59 \pm 2,18 \\
7,42 \pm 3,17 \\
(0,003) \\
\end{array}$ \\
\hline Educational status & $\begin{array}{l}\text { a.Primary school } \\
\text { b.Middle school } \\
\text { c.High school } \\
\text { d.University } \\
(p)^{\star}\end{array}$ & $\begin{array}{r}175(41,6) \\
165(39,3) \\
44(10,5) \\
36(8,6)\end{array}$ & $\begin{array}{r}175(41,6) \\
165(39,3) \\
44(10,5) \\
36(8,6) \\
>0,05 \\
\end{array}$ & $\begin{array}{r}3,39 \pm 0,88 \\
3,25 \pm 0,76 \\
3,18 \pm 0,68 \\
3,20 \pm 0,43 \\
>0,05\end{array}$ & $\begin{array}{r}3,46 \pm 0,63 \\
3,47 \pm 0,74 \\
3,46 \pm 0,57 \\
3,35 \pm 0,10 \\
>0,05\end{array}$ & $\begin{array}{r}7,64 \pm 2,53 \\
8,70 \pm 3,09 \\
8,60 \pm 3,33 \\
7,95 \pm 3,89 \\
>0,05 \\
\end{array}$ \\
\hline $\begin{array}{l}\text { Thinking about death } \\
\text { frequently }\end{array}$ & $\begin{array}{l}\text { Yes } \\
\text { No } \\
(p) \\
\end{array}$ & $\begin{array}{l}320(76,1) \\
100(23,9)\end{array}$ & $\begin{array}{r}3,84 \pm 0,59 \\
3,80 \pm 0,56 \\
(0,973) \\
\end{array}$ & $\begin{array}{r}3,34 \pm 0,18 \\
3,23 \pm 0,53 \\
(0,694) \\
\end{array}$ & $\begin{array}{r}3,41 \pm 0,68 \\
3,37 \pm 0,50 \\
(0,783) \\
\end{array}$ & $\begin{array}{r}7,89 \pm 3,17 \\
9,69 \pm 2,62 \\
(0,001) \\
\end{array}$ \\
\hline $\begin{array}{l}\text { Near-death } \\
\text { experience }\end{array}$ & $\begin{array}{l}\text { Yes } \\
\text { No } \\
\text { (p) }\end{array}$ & $\begin{array}{l}112(26,6) \\
308(73,4)\end{array}$ & $\begin{array}{r}3,96 \pm 0,67 \\
3,11 \pm 0,45 \\
(0,001) \\
\end{array}$ & $\begin{array}{r}3,33 \pm 0,67 \\
3,26 \pm 0,51 \\
(0,003) \\
\end{array}$ & $\begin{array}{r}3,44 \pm 0,62 \\
3,31 \pm 0,46 \\
(0,003) \\
\end{array}$ & $\begin{array}{r}9,52 \pm 2,85 \\
7,87 \pm 3,09 \\
(0,001 \\
\end{array}$ \\
\hline \multicolumn{2}{|l|}{ Total } & $420(100,0)$ & $3,64 \pm 0,56$ & $3,25 \pm 0,75$ & $3,47 \pm 0,66$ & $8,94 \pm 3,05$ \\
\hline
\end{tabular}

According to our research results, having a near death experience and having children are factors that increase death anxiety of elderly people. Elderly women have higher death anxiety, and death anxiety decreases with age. It was found that thinking of death frequently increases death anxiety (Table 3). 
Table 4. Factors affecting concept of good death and death anxiety (Multivariate analysis).

\begin{tabular}{|c|c|c|c|}
\hline \multicolumn{3}{|c|}{ GDS Subdimensions } & \multirow{2}{*}{$\begin{array}{l}\text { Death Anxiety } \\
\text { B }(95 \% \mathrm{Cl}) \mathrm{p}\end{array}$} \\
\hline $\begin{array}{l}\text { Psychosocial and Spiritual } \\
\text { Dimension B }(95 \% \mathrm{Cl}) \mathrm{p}\end{array}$ & $\begin{array}{l}\text { Personal Control } \\
\text { B }(95 \% \mathrm{Cl}) \mathrm{p}\end{array}$ & $\begin{array}{c}\text { Clinical } \\
\text { B }(95 \% \mathrm{Cl}) \mathrm{p}\end{array}$ & \\
\hline $\begin{array}{c}\text { Near-death experience: } \\
0,355(0,081-0,623) 0,001 \\
\text { Gender: } \\
0,254(0,067-0,252) 0,005 \\
\text { Child: } \\
0,177(0,017-0,340) 0,001\end{array}$ & $\begin{array}{c}\text { Near-death experience: } \\
0,360(0,076-0,613) 0,003 \\
\text { Gender: } \\
0,444(0,089-0,788) 0,002 \\
\text { Number of children: } \\
0,227(0,021-0,249) 0,001\end{array}$ & $\begin{array}{c}\text { Near-death experience: } \\
0,399(0,077-0,713) 0,003 \\
\text { Gender: } \\
0,375(0,118-0,527) 0,004 \\
\text { Child: } \\
0,186(0,077-0,393) 0,004\end{array}$ & $\begin{array}{c}\text { Near-death experience: } \\
0,350 \text { (0,087-0,719) } 0,001 \\
\text { Gender: } \\
0,415(0,188-0,522) 0,005 \\
\text { Child: } \\
0,196(0,063-0,397) 0,003 \\
\text { Age: } \\
0,296(0,051-0,403) 0,003 \\
\text { Thinking of death } \\
\text { frequently: } \\
0371(0,058-0,881) 0,001\end{array}$ \\
\hline $\begin{array}{l}\text { Linear regression } \\
\text { (backward regression): } \\
\text { df: } 14 ; \text { R:0.41; R2: } 0.19 \\
\text { Dubin Watson: } 0.897 \\
\text { ANOVA; } p=0.013\end{array}$ & $\begin{array}{c}\text { Linear regression } \\
\text { (backward regression): } \\
\text { df: } 14 ; \mathrm{R}: 0.47 ; \mathrm{R} 2: 0.21 \\
\text { Dubin Watson: } 0.948 \\
\text { ANOVA; } p=0.015\end{array}$ & $\begin{array}{c}\text { Linear regression } \\
\text { (backward regression): } \\
\text { df: } 14 ; \mathrm{R}: 0.43 ; \mathrm{R} 2: 0.17 \\
\text { Dubin Watson: } 0.823 \\
\text { ANOVA; } p=0.017\end{array}$ & $\begin{array}{c}\text { Linear regression } \\
\text { (backward regression): } \\
\text { df: } 14 ; \mathrm{R}: 0.56 ; \mathrm{R} 2: 0.25 \\
\text { Dubin Watson: } 1.972 \\
\text { ANOVA; } p=0.011\end{array}$ \\
\hline
\end{tabular}

In the study, it was found that according to the results of multivariate analysis, the importance given to all subdimensions of the concept of good death by female participants, those with near-death experience and those with children was statistically significantly higher (Table 4).

Table 5. Good Death Scale subdimensions and Death Anxiety correlations.

\begin{tabular}{|l|r|r|r|r|r|r|}
\hline $\begin{array}{l}\text { GDS Subdimensions and } \\
\text { Death Anxiety }\end{array}$ & Mean & $\begin{array}{r}\text { Standard } \\
\text { Deviation }\end{array}$ & $\mathbf{1}$ & $\mathbf{2}$ & $\mathbf{3}$ & $\mathbf{4}$ \\
\hline $\begin{array}{l}\text { Psychosocial and spiritual } \\
\text { subdimension (1) }\end{array}$ & 3,63 & 0,66 & 1 & & & \\
\hline $\begin{array}{l}\text { Personal control } \\
\text { subdimension (2) }\end{array}$ & 3,28 & 0,51 & $r=0,78^{\star}$ & 2 & & \\
\hline Clinical subdimension (3) & 3,41 & 0,81 & $r=0,81^{\star}$ & $r=0,73^{\star}$ & 3 & \\
\hline Death anxiety (4) & 8,62 & 2,75 & $r=0,51^{\star \star}$ & $r=0,47^{\star \star}$ & $r=0,53^{\star \star}$ & \\
\hline
\end{tabular}

When the correlations of the good death scale subdimensions were examined, it was found that the correlations of all subdimensions with each other were positive and highly significant, and there was a positive and moderately significant relationship between the subdimensions and death anxiety (Table 5). 


\section{DISCUSSION}

Death is one of the important issues that will continue to shape our lives as long as life itself continues to exist. Advances in science, technology and health have not eliminated people's helplessness, loneliness and anxiety in the face of death. Being aware that the end of life is approaching causes people to spend this period with despair and anxiety $(2,12)$.

Many studies have shown that age is the variable that is most associated with death anxiety. There are many studies that show that death anxiety decreases with increasing age in elderly individuals $(1,13)$. This aspect of our study is consistent with these studies in the literature (Table 3, $\mathrm{p} \leq 0.005$ )

In most studies on death anxiety and gender, as in our study, women's death anxiety was higher than that of men, and the difference was statistically significant (Table 3, $p \leq 0.005$ ) (14). Although the difference between anxiety scores was statistically insignificant in some of these studies, it was found that the mean score of women was higher than that of men $(1,15)$.

In some previous studies, the relationship between educational status, income and marital status and death anxiety was examined, and contradictory results were obtained $(9,15-17)$. In our study, we did not determine a statistically significant relationship between death anxiety and marital status, educational status and income in the elderly (Table 3, $p \geq 0.05$ )

Studies have shown that the frequency of thinking about death increases death anxiety in the elderly $(16,17)$. We have similarly found that as the frequency of thinking about death increases, death anxiety increases significantly in the elderly, and our findings are consistent with the literature (Table 3, p $\leq 0.001$ ).

In our study, unlike the other studies in the literature, we questioned whether the participants had children and had near-death experiences.
We found that those with children $(p \leq 0.003)$ and those with a near-death experience $(p \leq 0.001)$ had a higher rate of death anxiety than those without (Table 3).

In our study, we investigated, along with death anxiety, how a good death should look like for elderly individuals. One's point of view on how a good death should look like is closely related to how one wants to spend his/her last moments. In many studies on good death, how a good death should be having been questioned in different age groups and cultures $(3,4,12,18)$. In our literature review and research results, we have found that some topics on the idea of good death were the same for all societies and all segments of society. During the examinations of the answers to questions about the concept of good death in the clinical subdimension of the good death scale used in our study, we found that the highest score was received for the option "having a painless or substantially painless death" (3.92 \pm 0.81$)$ (19-22), which was consistent with the literature, while the highest score in the personal control subdimension was received for the option "ability to communicate until death" $(3.47 \pm 0.83)(21,23)$, and in the psychosocial and spiritual dimension "having an opportunity to say goodbye to loved ones" $(3.93 \pm 0.61)(2,12,20)$; these results are consistent with the literature.

In our study, we found that as the importance given to all subdimensions of good death increased, the death anxiety increased positively, and all subdimensions of good death had a significant correlation among themselves (Table 5); all the answers given to all subdimensions were statistically significantly correlated with gender (female), having children and having near-death experience (Table 4). In these aspects, our study is consistent with the literature $(10,12,22,24)$. Although Schwartz found that the subdimensions of good death had a significant relationship with variables of age, income and marital status (10), in our study we did not determine a significant re- 
lationship between subdimensions of good death and the variables of age, income, marital status, thinking of death frequently. We found no significant relationship between the dimensions (Table 3). We think that this is due to the fact that our research was limited only to elderly individuals. However, in the relevant literature on the subject, it can be seen that the relationship between good death and variables such as age, income, marital status, frequency of thinking about death and having near-death experience varies $(7,22,24,25)$.

Even though death is a concept existing in our lives like life, we do not like talking much about it. It seems that there is no definition of death that will fit all cultures and societies. Although there are many studies about anxiety and depression in elderly individuals in Turkey, there are very few studies on death anxiety, good death and the last period of life. Considering the average life expectancy in humans, studies conducted in order to explain death anxiety and how a good death should be

\section{REFERENCES}

1. Depaola SJ, Griffin M, Young JR, Neimeyer RA. Death anxiety and attitudes toward the elderly among older adults: The Role of gender and ethnicity. Death stud 2003;27(4):335-54. (PMID: 12749378).

2. Steinhauser KE, Clipp EC, McNeilly M, Christakis NA, Mclntyre LM, Tulsky JA. In search of a good death: Observations of patients, families, and providers. Ann Intern Med 2000;132(10):825-32. (PMID: 10819707).

3. Liu WM, Koerner J, Lam L, et al. Improved quality of death and dying in care homes: A palliative care stepped wedge randomized control trial in Australia. J Am Geriatr Soc 2019;16:192-6. (PMID: 31681981)

4. Pollock K, Seymour J. Reappraising 'the good death'for populations in the age of ageing. Age Ageing 2018;47:328-30. (PMID: 29518180).

5. Johnston B, Smith LN. Nurses? and patients? perceptions of expert palliative nursing care. J Adv Nurs 2006;54(6):700-9. (PMID: 16796662).

6. Hick F, Rees EA. A 'pain-free' death. Br Med Bull 2008;88(1):23-41. (PMID: 19036805). from the perspective of elderly individuals, whom we see close to death, will be guiding for both families and professional groups working with the elderly since our research results have revealed that there are universal findings about how people want to spend their last moments, and the most important one is a painless death. As a decent and fair life befitting human dignity is an indispensable right for all people, decisions regarding the last period of life and the desire for a good death are equally indispensable rights for all people and all age groups, and applications in practice should be shaped according to these needs.

\section{Disclosure Statement}

The authors declare they have no conflict of interest related to the research.

\section{Funding}

This study received no funding.

7. Yao CA, Hu WY, Lai YF, Cheng SY, Chen CY, Chiu TY. Does dying at home influence the good death of terminal cancer patients? J Pain Symptom Manage 2007;(2):3-6. (PMID: 17629664).

8. Templer DI. The construction and validation of a Death Anxiety Scale. J Gen Psychol 1970;82:165-77. (PMID: 4394812).

9. Akca F, Kose IA. Adaptation of Death Anxiety Scale (DAS): Validity and Reliability Studies. Turkish J Clinical Psychiatry 2008 Jun 1;11:7-16. [Internet] Available from: https://www.journalagent.com/kpd/ pdfs/KPD_11_1_7_16.pdf Accessed: 10.10.2019.

10. Schwartz CE, Mazor K, Rogers J, Yunsheng MA, Reed G. Validation of a New Measure of Concept of a Good Death. J palliative med 2003;6(4):4-7. (PMID: 14516499).

11. Fadıloglu C, Aksu T. Validity and reliability of good death scale. Journal of Ege University Nursing Faculty 2013 Feb 4;29(1):1-15. [internet] Available from: https://dergipark.org.tr/en/pub/egehemsire/ issue/49346/630301 Accessed: 10.10.2019. 
12. Hattori K, McCubbin MA, Ishida DN. Concept analysis of good death in the Japanese community. J Nurs Scholarsh 2006; 38(2):165-170. ( PMID: 16773921).

13. Chopik WJ. Death across the lifespan: age differences in death-related thoughts and anxiety. Death Stud 2017;41(2):69-77. (PMID: 27573253)

14. Madnawat AS, Kachhawa PS. Age, gender, and living circumstances: Discriminating older adults on death anxiety. Death Stud 2007;31(8):763-9. (PMID: 17853528).

15. Abdel-Khalek AM. Death anxiety in clinical and nonclinical groups. Death stud 2005;29(3):251-9. (PMID: 15818874)

16. Erdogdu MY, Ozkan M. The relationships between death anxiety with dispositional symptoms and sociodemographic variables of individuals from different religions. Inonu University Medical Faculty Journal 2007 Jan 1;14(3):171-9. [internet] Available from: https://arastirmax.com/tr/system/files/dergiler/5674/ makaleler/14/3/arastirmax-farkli-dini-inanislardakibireylerin-olum-kaygilari-ile-ruhsal-belirtiler-sosyodemografik-degiskenler-arasindaki-iliskiler.pdf Accessed: 25.10.2019.

17. Ozturk Z, Karakus G, Tamam L. Death anxiety in elderly cases. Anatolian Psych J 2011 Jul 15;12(1):3743. [Internet] Available from: http://tamam.cu.edu.tr/ aktd/death_anxiety.pdf Accessed: 25.10.2019.

18. Young HY, Kyoung NK, Jin $A H$, et al. Priorities of a good death according to cancer patients, their family caregivers, physicians, and the general population: a nationwide survey. Support Care Cancer 2018;26:3479-88. (PMID: 29682690).
19. Walter T. Historical and cultural variants on the good death. BMJ 2003;327: 218-20. (PMID: 12881270).

20. Vig EK, Davenport NA, Pearlman RA. Good deaths, bad deaths, and preferences for the end of life: A qualitative study of geriatric outpatients. J Am Geriatr Soc 2002;50:1541-8. (PMID: 12383152).

21. Jansen J, Schulz-Quach C, Eisenbeck N, et al. German version of the death attitudes profile-revised (DAPGR) - translation and validation of a multidimensional measurement of attitudes towards death. BMC Psychol 2019;11;7(1):61-7. (PMID: 31511068).

22. Akechi T, Miyashita M, Morita T, et al. Good death in elderly adults with cancer in Japan based on perspectives of the general population. J Am Geriatr Soc 2012;60:271-6. (PMID: 22332673).

23. Jeste DV, Graham S. In search of a good death: A good death is an oxymoron without consideration of mental health. Am J Geriatr Psychiatry 2019;27(5):4725. (PMID: 30871877).

24. Meier EA, Gallegos JV, Thomas LP, Depp CA, Irwin SA, Jeste DV. Defining a good death (successful dying); literature review and a call for research and public dialogue. Am J Geriatr Psychiatry 2016;24(4):261-71. (PMID: 26976293)

25. Yun YH, Kim YN, Sim JA, et al. Priorities of a good death according to cancer patients, their family caregivers, physicians, and the general population: a nationwide survey. Support Care Cancer 2018;10:3479-88. (PMID: 29682690). 